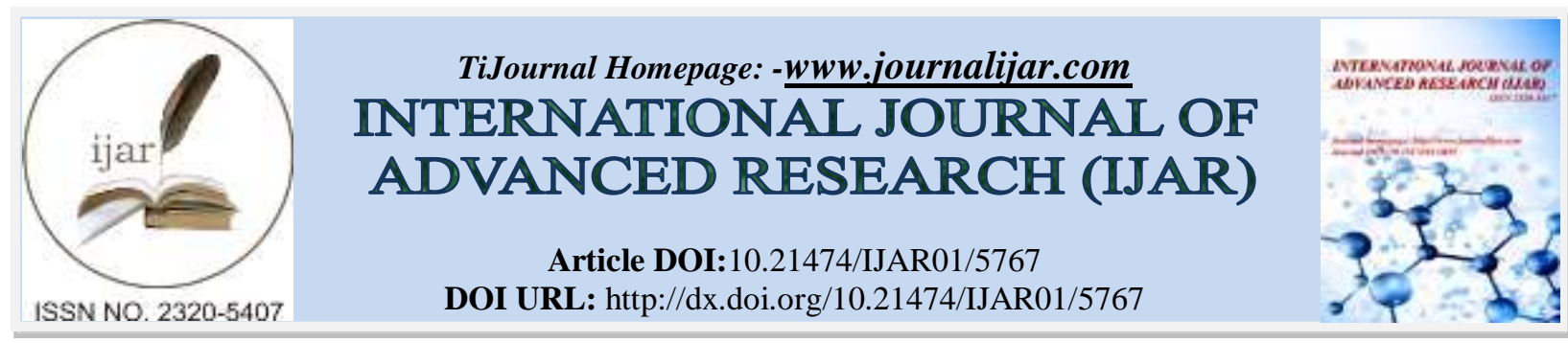

RESEARCH ARTICLE

\title{
RECONSTRUCTION ON THE LEGAL POLICY FOR HANDELING ERADICATING DEFORESTRATION BASED ON THE DIGNIFIED JUSTICE PERSPECTIVE.
}

\author{
Anwar Sodik, S.H., M.A., M.H ${ }^{1}$, Prof. Dr. Teguh Prasetyo SH. M. Si. ${ }^{2}$ and Dr. Hj. Sri EndahWahyuningsih, \\ S.H., M.Hum? \\ 1. Doctoral Student at the Faculty of Law Universitas Islam Sulatan Agung Semarang. \\ 2. Comisioer at the DKPP-RI \& Professor of Law at Universitas Kristen SatyaWacana. \\ 3. Lecturer in Law at the Faculty of Law Universitas Islam Sulatan Agung Semarang.
}

\section{Manuscript Info}

Manuscript History

Received: 04 September 2017

Final Accepted: 06 October 2017

Published: November 2017

Key words:-

Reconstruction, Legal Policy, Eradication, Deforestration, Dignified Justice

\begin{abstract}
Reconstruction is meant the act or process of rebuilding, re-creating, or reorganizing something. It could also meanta rebuilding of a broken, worn-out, or otherwise inoperative article in such a way that a new article is created. This legal meaning of reconstruction is relevant and useful for this research. As it has given an idea for rebuilding, recreating or reoranizing, and repairing any legal policy for handeling the eradication of the act of deforestration in Indonesia with a new policy on the same issue but is based on the perspective of dignified justice. It would be argued that in fact the previous policy,and the principles underlying the old legal policyhandeling the eradication of the act of deforestration has been worn-out, and appeared as not properly operative, or damaged. Therefore, it needs to be reconstructed with the new perspective. And the new perspective would be called as the dignified justice perspective.
\end{abstract}

Copy Right, IJAR, 2017,. All rights reserved.

\section{Introduction:-}

A legal meaning of reconstruction has been stipulated in the Black's Law Dictionary as: the act or process of rebuilding, re-creating, or reorganizing something -an expert in accident reconstruction. Relating to Patent, the Dictionary gave a meaning of a rebuilding of a broken, worn-out, or otherwise inoperative patented article in such a way that a new article is created, thus resulting in an infringement -the replacement of the patented article's essential parts was an infringing reconstruction rather than a permissible repair. With regards to a city, contry, industry, etc, the Dictionary has stated the legal meaning of the word reconstruction as the work that is done to repair damage to a city, country, industry, etc., esp. after a war. The word reconstruction has also been undestood in the context of constitutional issue as the process by which states that had seceded during the Civil War were readmitted into the Union during the years following the war (i.e., from 1865 to 1877 ) - the $13^{\text {th }}, 14^{\text {th }}$, and $15^{\text {th }}$ Amandements to the U.S. Constitution, Some said, this are lasting legacy of reconstruction ${ }^{1}$.

The legal meaning of reconstruction in the Black's Law Dictionary stated above is useful relevant for this research. As it has given an idea for rebuilding, recreating or reoranizing, repairing any previous and appeared defective legal

\footnotetext{
${ }^{1}$ Briyan A. Garner (Ed.), Black's Law Dictionary, Tenth Edition, Thomson Reuters, The Unite States of America, 2014, h., 1465.
} 
policy for handeling the eradication of the act of deforestration in Indonesia. It would be argued that in fact the previous policy, and the principles underlying it for handeling the eradication of the act of deforestration has been worn-out, and appeared as not properly operative, or damaged. Therefore, it needs to be reconstructed with the new perspective and the new perspective would be called as the dignified justice perspective.

\section{Indonesian Policy on Eradicating Deforestration:-}

A new legal policy in the handeling of the prevention and eradication of deforestration in Indonesia is stipulated in the Law of the Republic of Indonesia Number 18 of 2013 on the Prevention and Eradication of the Act of Deforestration $^{2}$. In this Act, forest is to mean a one whole ecosystem in the form of an area of lands consisting of alive and vital natural resources which is dominated by a heavily wooded area in the comunity of its environment which is interrelated each other or can not be separated one after the other.

Forest is a unity of ecosystem in the form of expanse of land containing biological resources dominated by trees in natural community environment that can not be separated from one to another. In the long term, forests can act as a buffer system of life (live supporting system) as well as a contributor to food providers (forestforfood production). Therefore it becomes a human duty to always think about preserving the forest, in order to make a positive contribution to life.

The legal policy has been formed based on the dignigied idea, the philosophycal consideration that Indonesia's forests covering $63 \%$ of the land area are the invaluable gifts and trusts of God Almighty ${ }^{3}$. The country share the world bigest of the forest resources. There is also expediency consideration based on the idea of dignified justice as well that there must be a proper management of Indonesia's forest so as to provide versatile benefits for the welfare of Indonesian society as well as the benefit of mankind in the world. The forest resources must be gracefully handled, used optimally and preserved for the greatest prosperity of the people of the present generation and also future generations. According to an environmental organization watchdog WALHI, Indonesia still has 10 percent of the world's tropical forests. This figures tends to decrease, however if forest damage is not immediately controlled.

One would argue that nowadays, forests as a life support system and a source of prosperity for the people in reality is steadily in declining condition. In the period that is not too long past, there has been a significant destruction of forests throughout Indonesia. From the latest data it has mentioned that deforestation has reached 101, 73 million hectares. That is, forest destruction has really crippled the potential as well as one of the nation's economic foundations. Therefore, it becomes a mutual comitment for the the government and the people to maintain the sustainability of forest resources optimally. There must be a policy to mend the old policy through which the carrying capacity for sustainably of the forest will be secured, and being taken care of as in acordance with the moral, justice, wisdom, and it must be thoughtful, open and accountable.

As mentioned above, the Indonesian nation is blessed with and obtain the trust from the God Almighty of having a natural resources that are priceless. Therefore the natural wealth must be taken care of and utilized as much as possible based on noble character, as an act of worshiping and the embodiment of gratitude to the One Almighty God (Tuhan Yang MahaEsa). This is the precious value in the Pancasila as the source of all sources of law in Indonesia.

There are several categories of natural resources related to the forest. They are in the form of production forest, protected forest, nature reserve area, nature conservation area, hunting park, forest products, plants and animals. All

${ }^{2}$ The Act has been promulgated to strenghten the Law of the Republic of ndonesiaNumber 41 of 1999 on Forestry.

${ }^{3}$ This is the legal philosophy in the first tenet of the Pancasila. Cf. TeguhPrasetyo, Pancasila the Ultimate of All the Sources of Laws (A Dignified Justice Perspective), Journal of Law, Policy and Globalization, International Institute for Science, Technology and Education (IISTE), Vol. 54, October 2016; Criminal Liability of Doctor in Indonesia (From A Dignified Justice Perspective), International Journal of Advanced Research (IJAR), 1(10); TeguhPrasetyo S. H. MS.i and Tri AstutiHandayani., Legal Aid Principle: (Dignified Justice Theory Perspective),International Journal of Advanced Research (IJAR), 1(10), 2016; Shallman, TeguhPrasetyo and Amin Purnawan, Public Service on Land Registration Based on the Dignified Justice, Journal of Advanced Research (IJAR), Int. J. Adv. Res.5(5), 154-163, 1016. 
of this natural resources category must be conserved and utilized with full sense of responsibility, because it has a production function, flood and erosion prevention, maintaining soil fertility, environmental conservation, and biodiversity conservation functions. In short all of these are considered as bearing the function as a buffer for life as well as for attraction for nature tourism and utilization of environmental services.

The definition of the forest according to the Law of the Republic of Indonesia No. 18 of 2013 is almost the same as the definition of the forest in the Law of the Republic of Indonesia No. 41 of 1999. It read in those laws that that forest is a unity of ecosystem in the form of land containing biological resources dominated by trees in the natural environment, one with others are inseparable. While forestry is defined as a system of concessions related to integrated forest, forest, and forest products.

Forest is meant a number of trees growing on a field that is wide enough, so that the temperature, humidity, light, wind and so no longer determines the environment, but is influenced by the plants/trees just as long as it is growing at a reasonably extensive and growing quite tightly (horizontal and vertical).

There are four elements contained on the forest definition as mentioned above, namely: the lement of a large field called forest soil; the element of trees (wood, bamboo, palm), flora and fauna; and the environmental elements and the elements of government determination. The first, second and third elements form a living alliance that can not be separated from one another. Understanding the forest here, embrace the concept of law governing the vertical line which covers the field (land), trees, flora and fauna, along with the environment as a unified whole.

The existence of the Government's determination of forests has a very important meaning, because with the establishment and the involvment of the government, via legal policy, the forest position becomes very strong. There are two important meanings of the Government's involvement through legal policy and that are in order that everyone is not arbitrary to chop, topped and or work on forest areas. The Government through the Ministry of Forestry is required to regulate the planning, designation, provision and use of forests in accordance with their functions, and to safeguard and protect forests. The objective of forest protection is to preserve the forest's function, as well as to maintain the quality, value, and usefulness of the results.

Based on the above understanding, it can be understood that there are two interests contained in the essence of the legal policy for the forest, namely: first, is that the forest that contains natural resources is a gift of God Almighty bestowed the Indonesian nation is a priceless wealth, which can be used as a national development capital (general explanation of Law No.41 of 1999).

Second, that the forest is an ecosystem unity in the communion of nature and the environment that can not be transferred from one another. In addition to having the benefits stated above as such, the forests also has the basic functions, which is tecologically, economically and socially. Because of its functions, then the forest needs to be protected.

According to legal policy in the Law of the Republic of Indonesia Number 18 Year 2013 on Prevention and Eradication of Forest Destruction, the definition of forest destruction is a process, method, or act of destroying forests through illegal logging, forest use without permission or usage permit contrary to the intent and purpose of the granting of licenses in the forest.

All of this deforestration acts must be eradicated by legal policy that has been established, which has been appointed, or being processed and commencement by the government. At this point one could argue that this is the reconstruction of the policy to prevent and eradicate deforestration using based on the dignified justice since it is based on the legal policy estamblished by the Indonesian Government and it could also be considered as a the manifestation of the spirit of the Indonesian people to protect their environmental system especially the forest.

The action should be the prevention of forest destruction with all efforts made to eliminate the chance of forest destruction. The eradication done with all efforts as a legal action against the perpetrators of the destruction of forests, either directly, indirectly, or any other relevant. That everything associated with the destruction of forests must be eradicated, because of forest destruction will lead to disaster. Forest destruction or forest security disturbance is any action taken by humans, animals, and natural factors in forest areas that potentially reduce the potential, function and benefits of forest resources from production, ecology, and socioeconomic aspects. 
The Government of Inodnesia as representing country that control forest resources should be able to manage it properly so as to provide a versatile benefits for the welfare of Indonesian society and boxed lahatan people in the world. Therefore, as it has been mentioned above, the forest resources must be handled gratefuly, used optimally and preserved for the greatest prosperity of the people of the present generation and future generations. There are two kinds of efforts to maintain, preserve and protect the rights of the State over the forest, the forest protection effort called technical security efforts of forest and forest protection efforts, or so-called forest punitive security measures.

Forest protection is an attempt to prevent forest destruction. There are five categories of forest destruction that need protection are: damage caused by workmanship/occupation of forest land illegally, the use of forest in defiance of its functions, and commercial forestry irresponsible. Forest destruction due to the removal of stones, soil and other minerals, as well as the use of tools that are inconsistent with the soil conditions. Forest destruction due to illegal logging and illegal logging.Forest damage due to livestock grazing and due to fire. Damage manmade forest products, pests and diseases as well as natural resources.

Lately, the destruction of forests has become more widespread and complex. The destruction occurs not only in production forests but has also penetrated into protected forests or conservation forests. The destruction of forests has evolved into a criminal offense that has tremendous and organized impacts and involves many parties, both nationally and internationally. The damage has reached an alarming level for the survival of the nation. Therefore, the handling of forest destruction using the legal policy in it must be done remarkably.

The problem of forest destruction is still a national issue that requires serious handling by all parties. The necessity of the above gain serious attention is not due to the high forms of violation of forest destruction. Increased violations related to forest destruction are easily recognized by the public not only through mass media reports, both print and electronic, but also from various data released by various institutions, both private and government.

Some examples of forest destruction that had become a public concern in between the case of mining in Lumajang East Java, forest and land fires in several areas in Sumatra and Kalimantan, and many more cases are more in the spotlight or public concern relating to the cases of forest destruction. Increasing cases of violations related to forest destruction that occurred in the midst of society is very alarming, especially if the case is not resolved properly.

Various policies related to the eradication of forest destruction have been widely formulated, this is a sign that the government's attention to this problem is relatively high. Some policies related to combating forest destruction, among them: the Constitution of the Republic of Indonesia 1945, the Fourt Amendment as a constitutional policy, which strictly regulates the importance of social welfare, as stated in Article 33 paragraph (3), which reads: "earth and water and the natural resources therein shall be controlled by the state and used for the greatest prosperity of the people".

In addition, Indonesia already has another legal policy in the Law no. 41 of 1999 on Forestry. Furthermore, Indonesia has also issued and enacted Law No.18 of 2013 on the Prevention and Eradication of forest destruction. But unfortunately, until now there are still many people who do not know the existence of these legal products, so that in the case of forest destruction comes the attitude of omission.

In short, the list of leal policy on the forest protection in the Indonesian System can be found in the Law No. 41 of 1999 on Forestry and also on the Law No.19 of 2000 on amendments to Law No.41 of 1999 on forestry. There is also Law No. 32 of 2009 on the Protection and Management of the Environment, the Law No. 18 of 2013 on the Prevention and Eradication of Forest Destruction, The Government Regulation no. 45 of 2004 on the Protection of Forests and Presidential Instruction of Indonesia No. 4 Year 2005 on Eradication of illegal logging in forest area and the circulation in the entire territory of the Republic of Indonesia.

Those mentioned above are the legal philosophical foundation related to the Forestry Law. It has been stated on those policies that the forest as a gift and a mandate of God Almighty conferred upon the Indonesian nation, is an invaluable natural wealth, which required thankful for Grace that he gave considered as a trust because the forest must be taken care of and nurtured with noble character in order to worship, as a manifestation of gratitude to God Almighty. 
Forest asnational capital development, have benefits real for life and livelihood nation Indonesia whether it is ecological, social, cultural, and economic benefits, balanced and dynamic. For that the forest must be managed, protected and utilized on an ongoing basis for prosperity Indonesian society, both present and future generations.

In this position forest has one determinant life support systems, in which it provides great benefits to mankind. Therefore, it must be preserved. Forests have role as balancer of the global environment, so association with world international and it become very important with the priority of national interests.

All that has been stated above is in line with the perspective of dignified justice derived from Pancasila and manifested further mandate in the Article 33 paragraph (3) of the 1945 Constitution of the State of the Republic of Indonesia (UUD 1945), which requires that the earth, water and natural resources contained therein are controlled by country and used for as much as possible prosperity of the people, then the organizer forestry always contain soul and spirit of democracy berkeadil early and sustained.

Therefore, the implementation of forestry must be done with the principle of benefit and sustainable, popular, justice, togetherness, openness, and integrity with the basis of noble and accountable. Forest tenure by the state is not an ownership, but the state authorizes the Government to regulate and administer all things related to Forest, region Forest, and result Forest, set forest areas and/or changing the status of forest areas, regulating and establishing legal relationships between people with forests or forest areas and forest products, and regulating legal action on forestry.

Associated with the ground or philosophical principle in the Act for the Prevention and Eradication of Forest Destruction, it is stipulated that Indonesia's forests are one of the largest tropical forests in the world, so that its existence becomes the cornerstone of the life of nations in the world, in particular in reduce the impact of global climate change.

The using of and its use of planned, rational, optimal, and responsible answer accordingly with ability power to support, as well as paying attention to the preservation of environmental functions and balance to support sustainable forest management and sustainable forestry development for the people's prosperity.

Sustainable forest development requires considerable effort because it still happening various forestry crimes such as illegal logging, illegal mining, and illegal plantations. The crime has caused state losses and damages life socio cultural and environment life is enormous, and has increased the global warming that has become issue national, regional, and international. As is known lately this is destruction the forest is becoming more widespread and complex, destructive it happens no only in the forest production, but too has penetrated into protected forests and conservation forests.

Forest destruction has developing be something follow criminal crime which has a tremendous and organized impact, and involves many parties, both nationally and internationally. The resulting damage has reached a very alarming level for the survival of the nation and state.

Handeling of the destruction of the forests have to be done remarkably well. Efforts to deal with forest destruction have actually been long do but not yet walk on effective and not showing results that optimal. P that between other caused by the existence of legislation which exist prior to explicitly regulating the organized crime of forest destruction. In addition, legal or regulatory requirements are required or in this case the law for forest destruction that destruction Forest organized could handled effectively and efficiently, and in order to provide deterrent effect to the perpetrators.

The Law on Preventing and Eradicating Forest Degradation focuses on eradicating the destruction of forests conducted in an organized manner, i.e., activities carried out by one group that structured, that composed on two persons or more and that Act on together on one time certain with aim do destruction Forest. Not included in inside is group community that residing within and/or around forests that do traditional cultivation and/or logging outside conservation forest areas and forest protected for necessities alone and not for commercial purposes.

Constitution Prevention and Eradication of Forest Destruction not including the community groups residing in or around it that indeed in the for conservation or attempted in conservation protected forest. It is for necessities 
own and not for commercial purposes. Exceptions to traditional shifting activities given to the community who have lived for generations within the forest area and have engaged in swidden activities following the tradition of their local wisdom established by the group.

In terms of sociological, worsening forest destruction in the world and in our own country so very concerned for the life to come. Most of the forests in Indonesia have been deforested, resulting in ecosystem damage and fewer natural resources. Influence of forest destruction is also an impact on global warming. Humans only think of their own benefits without thinking about the impacts caused by forest destruction.

Current forest conditions appear to be diminishing due to high rates of deforestation. Low socio-economic conditions especially as the impact of the economic crisis, the ownership of land is narrow, low income from agricultural products and a lack of business skills outside the agricultural sector to encourage people living around the forest to look for sources of income from forests that are closest to the residential area. This fact also can not be separated from the government's policy factor in the management of forest resources that negates the socio-cultural dimension of society. The existence, rights and knowledge of local communities that actually have a degree of wisdom in managing forests for sustainability and the economy are less recognized and respected, thus implicating the people not to have ownership and responsibility for forest protection.

In keeping with the preservation of forests that human life itself will have an impact on the level of welfare for natural resources is retained and made available to the future. Here also the government's role should be better in handling illegal logging or forest protection, forest preservation order is maintained. Governments should take firm action against irresponsible parties in illegal logging to be given severe penalties or severe sanctions to illegal loggers, this if done well without any favoritism it will deter the illegal loggers so as to have an effect on preservation of forest preservation and availability of natural resources that remain until the coming generation. Preservation of forests will actually have an impact on public welfare for the sustained preservation of forests so they still have the land to continue to be used as the agricultural sector, this creates a society still have a source of income to meet their basic needs and make this economic system.

Our country is currently a change, then the government should continue to follow the change by changing the old culture, and the need to improve forest management models. If all are willing to observe the Forestry Law that needs to be remembered is very simple but full of meaning is "Sustainable Forest Prosperous or prosperous society". Forests now degraded to the forest management models that invites the public would be better to create a sustainable forest.

Combating deforestation is still a chore for Indonesia, given there are still many cases of improper destruction of forests, among which the most concern is still the presence of both the individual involvement of law enforcement officers, government agencies, state enterprises and others. Basically, the emergence of various issues related to combating deforestation stems from various factors including not optimal institutional role in addressing the problems of forest destruction. Institutions are institutional good in the form of values in the culture, institutions in society and network cooperation that is not optimal of organizations that facilitate, advocate, socialize and synergies that still need to be improved.

Forest destruction activities currently running with a more open, transparent many parties involved benefit from this illegal logging activities. The mode usually done in forest destruction is by involving many parties and systematically and organized. In general, the actors whose role is labor/loggers, investors/financiers, providers of transport and security businesses (often as a safety effort is of the bureaucracy, government officials, military, police). These actors will then work together to benefit. Below is a table in the collected data regarding the ever handling of eradication of forest destruction by the Police in Kendal area in the Central Java Province of Indonesia..

Table.1:-Number of Cases Destruction of forests handled by the Police

\begin{tabular}{|c|c|c|c|}
\hline CASE & \multicolumn{3}{|c|}{ YEAR } \\
\hline & 2012 & 2013 & 2014 \\
\hline Destruction of forests (illegal logging) & 10 & 6 & 17 \\
\hline
\end{tabular}

(Source: PerumPerhutani KPH Kendal) 
From the above data, it is still found many eradication of forest destruction conducted by the police that the legal process is less than the maximum. Polri as one of the institutions responsible for the upholding of the law is of course claimed its participation in supporting the realization of the eradication of forest destruction. Apparently from the destruction of forests elimination programs are handled or reported only forest destruction in the form of illegal logging (illegal logging) only when there are a lot of cases or issues related to the destruction of forests is very complex. Currently legal products made by the Government of Indonesia are already quite a lot, but its application is still very weak. Handling cases of forest destruction is less serious and seem to give a free space for the perpetrators of forest destruction to justify themselves.

Based on the description of the above mentioned problems, the title taken in this study: Rekon s truksi Policy Eradication Law in Handling Forest Destruction based on values of justice.

\section{Conclusion:-}

As a product of reconstruction mentioned above, a legal policy has been formed by the Indonesian authorities based on the dignigied justice idea, the philosophycal consideration that Indonesia's forests covering $63 \%$ of the land area are the invaluable gifts and trusts of God Almighty ${ }^{4}$. The country share the world bigest of the forest resources. There is also expediency consideration based on the idea of dignified justice as well that there must be a proper management of Indonesia's forest so as to provide versatile benefits for the welfare of Indonesian society as well as the benefit of mankind in the world.

The forest resources must be gracefully handled, used optimally and preserved for the greatest prosperity of the people of the present generation and also future generations. According to an environmental organization watchdog WALHI, Indonesia still has 10 percent of the world's tropical forests. This figures tends to decrease, however if forest damage is not immediately controlled.

\section{Bibliography:-}

1. The Law of the Republic of IndonesiaNumber 41 of 1999 on Forestry;

2. The Law of the Republic of Indonesia Number 41 of 1999 on Forestry and also on the Law of the Republic of Indonesia Number 19 of 2000 on amendments to Law of the Republic of Indonesia Number 41 of 1999 on forestry;

3. The Law of the Republic of Indonesia Noumber 32 of 2009 on the Protection and Management of the Environment;

4. The Law of the Republic of Indonesia Number 18 of 2013 on the Prevention and Eradication of Forest Destruction;

5. The Government Regulation No. 45 of 2004 on the Protection of Forests;

6. Presidential Instruction of Indonesia No. 4 Year 2005 on Eradication of illegal logging in forest area and the circulation in the entire territory of the Republic of Indonesia.

7. TeguhPrasetyo, KeadilanBermartabat: PerspektifTeoriHukum, CetakanPertama, Nusa Media, Bandung 2015.

8. TeguhPrasetyo, SistemHukumPancasila, Sistem, SistemHukum dan PembentukanPeraturanPerundang-Undangan, EdisiPertama, Nusa Media, Bandung, 2016

9. Prof. Dr. TeguhPrasetyo, SH., M. Si., Pancasila the Ultimate of All the Sources of Laws (A Dignified Justice Perspective), Journal of Law, Policy and Globalization, International Institute for Science, Technology and Education (IISTE), Vol. 54, October 2016;

10. Prof. Dr. TeguhPrasetyo, SH., M. Si., Criminal Liability of Doctor in Indonesia (From A Dignified Justice Perspective), International Journal of Advanced Research (IJAR), 1(10);

11. Prof. Dr. TeguhPrasetyo, SH., M. Si., and Tri AstutiHandayani., Legal Aid Principle: (Dignified Justice Theory Perspective),International Journal of Advanced Research (IJAR), 1(10), 2016;

12. Shallman, Prof. Dr. TeguhPrasetyo, SH., M.Si. and Amin Purnawan, Public Service on Land Registration Based on the Dignified Justice, Journal of Advanced Research (IJAR), Int. J. Adv. Res.5(5), 154-163, 1016.

This is the legalphilosophy in the first tenet of the Pancasila, as indicated in the PancasilaLegal System, See, TeguhPrasetyo, SistemHukumPancasila, Sistem, SistemHukum dan PembentukanPeraturanPerundang-Undangan, EdisiPertama, Nusa Media, Bandung, 2016; TeguhPrasetyo, KeadilanBermartabat: PerspektifTeoriHukum, CetakanPertama, Nusa Media, Bandung 2015. 